\title{
The Development of Food and Nutrition Security Index at Provincial Level in Indonesia
}

\author{
Anggit Gantina ${ }^{1,2 *}$, Drajat Martianto ${ }^{3}$, Dadang Sukandar ${ }^{3}$ \\ ${ }^{1}$ Postgraduate in Nutrition Sciences, Department of Community Nutrition, Faculty of Human Ecology, \\ IPB University, Bogor 16680, Indonesia \\ ${ }^{2}$ Agency for Food Security, Ministry of Agriculture, Jakarta 12550, Indonesia \\ ${ }^{3}$ Department of Community Nutrition, Faculty of Human Ecology, IPB University, Bogor 16680, Indonesia
}

\begin{abstract}
This study aimed to develop a novel Food and Nutrition Security (FNS) index to be implemented at provincial level in Indonesia. Principal component analysis was used to calculate food and nutrition security index based on 23 indicators, data were obtained from provincial and national public report published in 2010 and 2013. These indicators were further grouped into three different dimension of food availability, food accessibility and food utilization. Principal Component Analysis (PCA) was then used to calculate each aspect and the FNS indices. The index was later used to categorize food and nutrition security performance of a region into one of three levels, namely secure, vulnerable or insecure. The application of this new FNS index found that most of Indonesia's regions $(87.5 \%)$ were categorized as vulnerable $(50.0 \%)$ and insecure $(37.5 \%)$ and only $12.5 \%$ had high food and nutrition security performances in 2013. Among all provinces, Bali had the best performance in 2013, while East Nusa Tenggara had the lowest performance in 2010 and 2013. In 2013, the food availability status of all the provinces were categorized as secure. However, their status on food accessibility and food utilization showed many of them fell into vulnerable and insecure categories. Hence, the effort to increase the national food and nutrition security performance should focus on improving food accessibility and food utilization.
\end{abstract}

Keywords: food accessibility, food availability, food utilization, Indonesia

\section{INTRODUCTION}

Global efforts to reduce hunger and nutrition problems, as well as to increase food security, have started since 1948 (Pangaribowo et al. 2013; Capone et al. 2014; Hjelm et al. 2016). Food and nutrition security concept is used by Food and Agriculture Organization (FAO) and other international to integrate nutritional aspect in food security development (Committee on World Food Security (CFS) 2012; Aliaga \& Chaves-Dos-Santos 2014; Fanzo 2014).

A number of food security indicators have been established at global level, FAO classified the food security indicators into four dimension, of food availability, food accessibility, food utilization and stability (FAO 2016; Headey \& Ecker 2013). World Health Organization (WHO) also determined 17 indicators to assess the nutritional acheivement (WHO 2015). Another study by Pangaribowo et al. (2013) classified food and nutrition security indicators into different level, of individual, household, and regional levels. In Indonesia, at the national level the Food Security Council issued a strategic policy document of Food and Nutrition Action Plan (SPFNAP) in 2016, which determined the matrix of food and nutrition achievement covering 28 indicators (Suryana et al. 2016).

Food and nutrition security is multidimensional (Suryana 2014), thus the indicators to assess food and nutrition security achievement should include a set of indicators (Pemberton et al. 2016). The study results from Leroy et al. (2015) indicated that composite indicators were better for measuring food security achievement. Several indicies have been developed globally, there are The Global Hunger Index by International Food Policy Research Institute (IFPRI 2014), Rice Bowl Index (RBI), and Human Development Index (HDI). Related to assessment of FNS level, various measures have also been developed at global level (Herforth \& Ballard 2016), one of them was the Global Food Security Index (GFSI) which was developed by The Economist Intelligence Unit

"Corresponding Author: tel:+628157123667, email: anggitgantina@gmail.com 
(EIU) (Pangaribowo et al. 2013). This measure is approriate to evaluate food security situation at country level, whereas for assessment at provincial level the GFSI needs to be adjusted due to the lack of data for some indicators.

The GFSI developed by EIU can only be used for country level. At national level, the food security indicators and measures have also been established by The World Food Programme (The Food Security and Vulnerability Atlas of Indonesia (FSC \& WFP 2009 \& 2015a); Faharuddin (2012); Nurhemi et al. (2014). However, these tools and measures need to be redeveloped to suit relevant data available at the provinsial level. Based on the pausity of multi dimensional assessment tools for provincial level data, this study aimed to develop a novel FNS index, integrating the many food and nutrition security dimensions for provincial level in Indonesia. The index can be used by local government to evaluate the performance of their food and nutrition security progress and development.

\section{METHODS}

\section{Design, location and time}

This was an explanatory study, using a cross sectional study design. The secondary data was collected between March to August in 2017. The research was conducted following several stages; identification of potential indicators, selection of indicators, assessment of index and clusteritation of provinces.

\section{Sampling}

This study used secondary data published in year 2010 and 2013. The sampling method was convenience sampling, involving data from 32 provinces which reflect the Food and Nutrition Security (FNS) dimension (food availability, food accessibility, and food utilization). The food utilization dimension data is available in the national basic health survey reported every three years (the latest are year 2010 and 2013), hence this study used data published in 2010 and 2013 for all the other FNS dimension.

\section{Data collection}

Food availability dimension data was collected from publication of National Food Balance Sheet from 32 Provinces published in 2010 and 2013, gathered from the Food Security
Agency-Ministry of Agriculture of Indonesia. The data of food accessibility dimension was collected from The National Socioeconomic Survey by Statistics Indonesia year 2010 and 2013. Data on the rice prices were collected from publication of food prices in 2010 and 2013 gathered from the Ministry of Trade. Dimension of food utilization data was collected from publication and website of related institution. The food consumption level was taken from the Indonesian Food Directory published in 2015 by the Food Security Agency-Ministry of Agriculture. Access to clean water and sanitation were collected from Statistics Indonesia, and data on nutritional status was collected from the Basic Health Research published in 2010 and 2013. Data on food safety and foodborne diseases was collected from the National Agency of Drug and Food Control/NA-DFC yearly report published in 2010 and 2013.

\section{Data analysis}

Identification of potential indicators.

Potential indicators were identified based on published literature (FAO, WHO, National Action Plan for Sustainable Development Goals, National Medium-Term Development Plan and SP-FNAP).

Selection of indicators. There are 78 indicators identified in the first step, the research team then conducted a group dicussion and consultation to screen the and narrow down the indicators to 51 potential indicators as longlist indicators of food and nutrition security dimension. Further, the research team conducted a qualitative selection process to narrow down the potential indicators using the following criteria: the relevance to food and nutrition security concept, redundancy elimination, data availability and representation of meanings this process resulted in 23 selected indicators. These indicators were grouped into three dimension of food security, according to FAO-STAT food security indicators classification (FAO 2016) (Figure 1).

According to FAO-STAT food security indicators classification (FAO 2016), 23 selected indicators then were grouped into three food security dimension: (a) five indicators for food availability dimension $\left(\mathrm{X}_{1}\right.$ : percentage of irrigated land; $\mathrm{X}_{2}$ : energy availability level/EAL; $\mathrm{X}_{3}$ :protein availability level/PrAL; $\mathrm{X}_{4}$ :proportion 


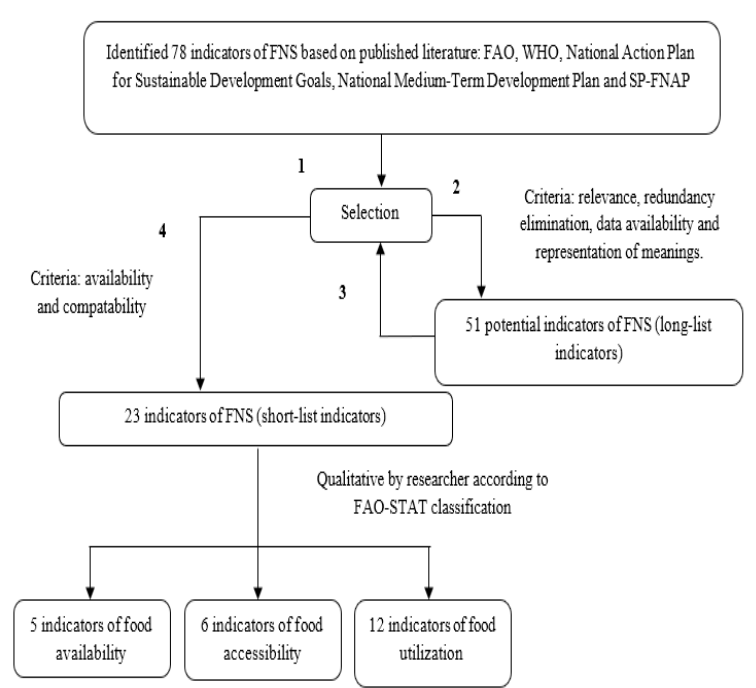

Figure 1. Stages of FNS indicators selection

of energy availability from cereals (non-wheat) and tubers, $\mathrm{X}_{5}$ : availability of animal source foods/ ASF); (b) six indicators of food accessibility dimension $\left(\mathrm{X}_{6}\right.$ : percentage of paved road; $\mathrm{X}_{7}$ : GDRP/Gross Regional Domestic Product per capita; $\mathrm{X}_{8}: \mathrm{CPI} /$ Consumer Price Index of the foodstuffs; $\mathrm{X}_{9}$ : proportion of people with energy intake $>1800 \mathrm{kcal} /$ day; $X_{10}$ : percentage of people living above the poverty line; and $\mathrm{X}_{11}$ : stability of rice prices $(1 / \% \mathrm{CV}))$; (c) 12 indicators of food utilization dimension $\left(\mathrm{X}_{12}\right.$ : energy intake level; $\mathrm{X}_{13}$ : protein intake level; $\mathrm{X}_{14}$ : Desirable Dietary Pattern Score; $\mathrm{X}_{15}$ : percentage of households with access to clean water; $\mathrm{X}_{16}$ : percentage of households with adequate sanitation access; $X_{17}$ : prevalence of non-wasted under-five children; $\mathrm{X}_{18}$ : prevalence of non-stunted under-five children; $\mathrm{X}_{10}$ : prevalence of non-underweight under-five children; $\mathrm{X}_{20}$ : prevalence of exclusively breastfed infants at the age of $<6$ months; $X_{21}$ : percentage of non-underweight adults; $\mathrm{X}_{22}$ : percentage of healthy and safe food; and $X_{23}$ : frequency of foodborne diseases).

Index calculation. The Principal Component Analysis (PCA) was used to calculate the food availability index (5 indicators), food accessibility index (6 indicators), food utilization index (12 indicators), and the provincial food and nutrition security index (23 combined indicators of all dimension). Index development using PCA had also been used by Ariawan (2006) to calculate socioeconomic index using Indonesia Demographic and Health Survey data in 2002-
2003. Napoli et al. (2011) used PCA to calculate the food insecurity multidimensional index of 61 countries in the world using 1995-2009 time series data. PCA method is an algorithm with an orthogonal principle, which is used to transform the allegedly correlated variables resulting in a set of uncorrelated linear values (Karamizadeh $e t$ al. 2013; Jollife \& Cadima 2016).

The calculation of food and nutrition security index was performed through the following steps: (1) a set of food and nutrition security variables was analyzed using PCA, resulting in aij eigenvector value (indicator coefficient/weight); (2) the values of origin variables were standardized to $z$-score with the formula $z_{i j}=\frac{x_{i j}-\bar{x}_{i j}}{s_{i}}$ in which $\mathrm{z}$ value was the standard variable, $x_{i j}$ was the initial variable, $\bar{x}_{i j}$ was the mean of $i^{\text {th }}$ variable $\mathrm{j}^{\text {th }}$ matrix, and $s$ was the standard deviation of the $\mathrm{j}^{\text {th }}$ matrix; (3) calculation of food and nutrition security index total score of each province; i.e. multiplication result of standard variable (z-score) with its variable coefficient $\left(\alpha_{i j}\right)$. Normalizing the variable into $\mathrm{z}$-score resulted in zero mean and standard deviation of 1 , with negative to positive total score (index). The mathematical models used to calculate the Availability Index (AV), Accessibility Index (AC), Utilization Index (UT), and Food and Nutrition Security Index (FNSI) were written in equations $1-4$.

$$
\begin{aligned}
& \mathrm{AV}=\alpha_{1 J} X_{1}+\alpha_{2 J} X_{2}+\ldots \ldots+\alpha_{5 J} X_{5} \ldots \ldots \ldots \ldots(1) \\
& \mathrm{Ac}=\alpha_{6 J} X_{6}+\alpha_{7 J} X_{7}+\ldots \ldots+\alpha_{11 J} X_{11} \ldots \ldots \ldots \ldots(2) \\
& \mathrm{UT}=\alpha_{12} X_{1}+\alpha_{13 J} X+\ldots \ldots+\alpha_{23 J} X_{23} \ldots \ldots \ldots(3) \\
& \mathrm{FNSI}=\alpha_{1 J} X_{1}+\alpha_{2 J} X_{2}+\ldots \ldots+\alpha_{23 J} X_{23} \ldots \ldots \ldots(4)
\end{aligned}
$$

$\mathrm{X}_{1}-\mathrm{X}_{23}$ is food and nutrition security variables and alpha $\mathrm{ij}\left(\alpha_{\mathrm{ij}}\right)$ is the coefficient of $\mathrm{i}^{\text {th }}$ variable $\mathrm{j}^{\text {th }}$ matrix (eigenvector value).

The first principal component always performed the determination of PCA, although it was subjective (Jollife \& Cadima 2016). According to Jollife and Cadima, this study used the first principal component (PC1) with a maximum variance value, it could explain the original information. The food and nutrition achievement were classified based on each indicator cut off. The cut off was decided by desk study analysis referring to the standards or targets of FNS indicators.

Dimension of food availability cut off referring to Food and Nutrition Action Plan 2010-2014, FSVA gathered from Food Security Agency (FSA) $2009 \& 2015 \mathrm{a}$, The cut off of food 
accessibility dimension referring to National Food and Nutrition Action Plan Document (Suryana et al. 2016), Statistics Indonesia report 2014 and FSA (2015a). Dimension of food utilization cut off referring to the standards or targets of Midterm Development Planning 2010-2014 (MoNDP 2010), Strategic Planning of MoA 2010-2014 (MoA 2010), Strategic Planning of MoH 20102014, Nutrition Information Landscape System (WHO 2012), and Strategic Plan of NA-DFC (2010). Based on these standards or targets, each indicators of this study were categorized into: high (secure), middle (vulnerable), and low (insecure). The value of each categorized were classified based on researcher analysis. Then all of data of each categorized proccesed with PCA and resulted FNS criteria, as seen in Table 1. These criteria were then used to classified the provincial food and nutrition security achievement. Data processing and analysis were performed using Microsoft Excel version 2010 and SAS program version 9.4 .

\section{RESULTS AND DISCUSSION}

\section{Food and nutrition security index}

The index was calculated for each pillar and for the food and nutrition security composite.

Food availability index (AV). Food availability index was calculated using the following mathematical models:

$\mathrm{AV}_{2010}=0.232$ Irrigated Land $+0.564 \mathrm{EAL}+0.549$

PrAL +0.519 Cereals +0.239 animal protein $\mathrm{AV}_{2013}=0.086$ Irrigated Land $+0.573 \mathrm{EAL}+0.57$

$\operatorname{PrAL}+0.539$ Cereals +0.214 animal protein

The national food availability index was -0.002 in 2010 and decreased to -0.29 in 2013 (Table 2). National level assessment showed that food availability domain is secure. However, provincial level assessment showed diverse result with Gorontalo Province occupied the top position in food availability aspect in 2010 and 2013. The main drivers were the high energy and protein availability levels, high proportion of energy availability from cereals (non-wheat) and tubers, as well as the animal protein availability.

Food accessibility index (AC). The calculation of food accessibility index used the following mathematical models:

$\mathrm{AC}_{2010}=0.489$ paved road +0.221 capita GRDP $-0.486 \mathrm{CPI}+0.256$ food secure +0.532 non poor
Table 1. Cut-off values and index categories

\begin{tabular}{lccl}
\hline \multirow{2}{*}{\multicolumn{1}{c}{ Index }} & \multicolumn{2}{c}{ Cut-off values } & Categories \\
\cline { 2 - 3 } & 2010 & 2013 & \\
\hline Food and & $2.13-4.63$ & $2.68-8.18$ & Secure \\
nutrition & $0.31-2.12$ & $-1.45-2.67$ & Vulnerable \\
security & $<0.31$ & $<-1.45$ & Insecure \\
& $-2.48-3.72$ & $-2.99-3.95$ & Secure \\
Food & $-3.26--2.49$ & $-3.72--3.00$ & Vulnerable \\
availability & $<-3.26$ & $<-3.72$ & Insecure \\
& $3.12-6.86$ & $2.23-4.09$ & Secure \\
Food & $0.44-3.11$ & $-0.25-2.22$ & Vulnerable \\
accessibility & $<0.43$ & $<-0.26$ & Insecure \\
& $-0.23-3.74$ & $1.19-6.57$ & Secure \\
Food & $-1.80--0.24$ & $-2.38-1.18$ & Vulnerable \\
utilization & $<-1.81$ & $<-2.38$ & Insecure \\
&
\end{tabular}

Source: Ministry of National Development Planning (2010); Food Security Agency (2009 \& 2015a); Statistic Indonesia (2014); National Agency of Drug and Food Control of Republic Indonesia (2010); Ministry of Agriculture (2010); World Health Organization (2012) analyzed using PCA

\section{-0.352 rice price}

$\mathrm{AC}_{2013}=0.547$ paved road -0.132 capita GRDP + $0.293 \mathrm{CPI}+0.627$ food secure +0.415 non poor -0.178 rice price

$\mathrm{X}_{12}-\mathrm{X}_{23}=$ variables' values as stated in method

The national food accessibility index was slightly increased in 2013 (Table 2), from insecure category in 2010 to vulnerable category in 2013. This achievement was influenced by the alighting of the poor population in 2013. Based on the data of Statistics Indonesia (2016), the proportion of people living below the poverty line has decreased to 11.37 percent in March 2013 or around 28.07 million people. In terms of food accessibility index, the top province are Bali (index value of 3.67 in 2013) and Bangka Belitung (index value of 4.2 in 2010) (Table 2). The low proportion of the poor population in the two provinces indicated that the economic access to food was good. The increased of Bali GDRP/ capita (IDR 28,129.7 in 2013) and the decreasing proportion of people living below the poverty line influenced the Bali province food accessibility achievement (Finkayana \& Dewi 2016).

Food utilization index (UT). Food utilization index was calculated using the following mathematical models:

$$
\begin{gathered}
\mathrm{UT}_{2010}=0.069 X_{12}+0.138 X_{13}+0.108 X_{14}-0.214 X_{15}+ \\
0.399 X_{16}+0.293 X_{17}+0.468 X_{18}+0.497 X_{19}+0.105 \\
X_{20}-0.389 X_{21}-0.206 \alpha 22 \mathrm{j} X_{22}-0.006 X_{23}
\end{gathered}
$$


$\mathrm{UT}_{2013}=0.155 X_{12}+0.332 X_{13}+0.236 X_{14}+0.391 X_{15}$ $+0.437 X_{16}+0.214 X_{17}+0.405 X_{18}-0.019 X_{20}-0.299$ $X_{21}-0.041 \propto 22 \mathrm{j} X_{22}+0.099 X_{23}$

$\mathrm{X}_{12}-\mathrm{X}_{23}=$ variables' values as stated in method

The national level food utilization index falls into the vulnerable category (0.73) in 2013. Bali Province (2013) and Riau Islands Province (2010) are the provinces with the highest food utilization performance. This due to their energy and protein intake levels (FSA 2015b), people's access to adequate sanitation and high prevalence of non-stunted under-five children in the two provinces (MoH 2013). The lowest performance of food utilization was found in East Nusa Tenggara Province (Tabel 2). Two-thirds of all households in Papua and East Nusa Tenggara had no adequate access to sanitation (proportion of $>70 \%$ ) (MoH 2013). A study by Tono et al. (2016) also found high ratio of households without adequate toilet facilities in most villages in the province which associated with the low nutrition status in the region.

Composite index (FNSI). Food and nutrition security index was calculated by the following mathematical models:

$\mathrm{FNSI}_{2010}=-0.065 X_{1}-0.181 X_{2}+0.063 X_{3}-0.261 X_{4}+$ $0.193 X_{5}+0.241 X_{6}+0.253 X_{7}-0.257 X_{8}+0.079 X_{9}+$ $0.3 X_{10}-0.169 X_{11}^{6}-0.056 X_{12}+0.085 X_{13}+0.023 X_{14}$ $-0.188 X_{15}+0.354 X_{16}+0.06 X_{17}+0.369 X_{18}+0.374$ $\mathrm{X}_{19}-0.185_{20}-0.184 X_{21}-0.143 X_{22}-0.004 X_{23}$ FNSI $_{2013}=0.082 X_{1}-0.144 X_{2}-0.053 X_{3}^{22}-0.177 X_{4}^{23}+0.0$ $42 X_{5}+0.259 X_{6}+0.189 X_{7}+0.091 X_{8}+0.217 X_{9}+$ $0.264 X_{10}+0.016 X_{11}+0.103 X_{12}+0.276 X_{13}+0.182$ $X_{14}+0.346 X_{15}+0.377 X_{16}+0.138 X_{17}+0.352 X_{18}+$ $0.354 X_{19}+0.016 X_{20}-0.211 X_{21}-0.05 X_{22}+0.084 X_{23}$ $\mathrm{X}_{1}-\mathrm{X}_{23}=$ variables' as stated in method

Based on the above calculation, the Food and nutrition security performance in Indonesia is categorized as vulnerable (FNSI 0.63) in 2013 (Table 2). Although the national food availability index performance is secure, the food accessibility index was categorized as vulnerable on both of the physical and economic access to food. Suryana et al. (2016) explained that food availability aspect (the income inequality problem, variability of food prices and poverty problem) are persitent obstacles for the national food and nutrition development.

The application of this novel index showed that four provinces (Bali, Jakarta, Yogyakarta and Riau Island) have the highest performance on food and nutrition index in 2013 (Table 2). The high FNS achievement in the provinces were influenced by the relatively good achievement on the dimension of food accessibility. This condition indicated that food accessibility aspect is a significant determinants for food and nutrition security achievements, after the food availability aspect was fulfilled. While at the same time in these provinces, the slightly good achievement of food accessibility dimension also contributes to their achievement in the food utilization dimension.

\section{Profile of food and nutrition security at provincial level in Indonesia}

At the national level, most of the regions in Indonesia (84.4\%) were categorized as vulnerable and insecure in 2010 (Figure 2). The low score was associated with the low achievement in the food accessibility dimensions as reflected by the proportion of food-secure population, people living below the poverty line, and the increase in food prices that triggered the inflation rate, especially in Papua, Maluku and Nusa Tenggara.

Food and nutrition security achievement in 2013 was slightly better than in 2010, as can be seen in Figure 2 and 3 that the food and nutrition security index scores increased at the national level and in some provinces in 2013. The improvement from insecure to vulnerable categories was found in 16 provinces, and the secure category was found in four provinces. However, there were still 12 provinces that fell into insecure category (Figure 3 ).

The low achievement in food accessibility dimension hindered improvement in nutrition, thus affected the human resources development in the country. The Global Food Security Index (affordability, availability, quality and safety) report showed that Indonesia was ranked $71 \mathrm{st}$ (EIU 2016) and slightly increased to 69th (EIU 2017) the next year, this achievement still far below Thailand, Vietnam, and Srilanka (EIU 2017).

The performance of provincial food and nutrition security in 2013 slightly different with 2010, which were characterized by the high proportion of households with adequate sanitation access $(\mathrm{PC} 1=0.378)$, high prevalence of non-underweight under-five children 
Gantina et al.

Table 2. Food and nutrition security indices based on rankings by province

\begin{tabular}{|c|c|c|c|c|c|c|c|c|c|}
\hline \multirow{2}{*}{ Rank } & \multirow{2}{*}{ Province } & \multicolumn{4}{|c|}{2010} & \multicolumn{4}{|c|}{2013} \\
\hline & & FNSI & AV & $\mathrm{AC}$ & UT & FNSI & $\mathrm{AV}$ & $\mathrm{AC}$ & UT \\
\hline 1 & Bali & 2.6 & -1.1 & 2.0 & 1.5 & 5.7 & -1.6 & 3.7 & 4.3 \\
\hline 2 & Special Jakarta & 3.7 & 0.7 & 1.6 & 2.0 & 4.4 & 0.8 & 0.6 & 3.5 \\
\hline 3 & Special Region of Yogyakarta & 1.6 & 0.4 & 0.6 & 2.4 & 4.2 & 0.1 & 2.3 & 4.2 \\
\hline 4 & Riau Islands & 4.4 & -1.9 & 2.2 & 3.7 & 4.1 & -1.8 & 0.01 & 4.0 \\
\hline 5 & East Kalimantan & 1.6 & -1.8 & -0.6 & 1.3 & 2.4 & -1.5 & -1.8 & 1.9 \\
\hline 6 & Banten & 2.4 & -2.3 & 1.4 & 1.6 & 2.3 & -2.5 & 1.5 & 1.5 \\
\hline 7 & Bangka Belitung & 4.2 & 2.8 & 2.3 & 2.1 & 2.0 & -1.1 & 1.1 & 1.1 \\
\hline 8 & North Sulawesi & 1.9 & 0.5 & -0.3 & 3.3 & 1.9 & 1.8 & 1.2 & 2.4 \\
\hline 9 & West Java & 2.1 & -1.0 & 1.5 & 1.6 & 1.1 & -0.3 & 1.2 & 0.6 \\
\hline 10 & East Java & -0.3 & 1.6 & 1.0 & -1.4 & 0.91 & -1.2 & 0.5 & 0.3 \\
\hline 11 & Central Java & 0.3 & 0.7 & 1.0 & -0.3 & 0.74 & 0.1 & 0.5 & 0.7 \\
\hline 12 & Southeast Sulawesi & -2.0 & -1.2 & -1.2 & -2.6 & 0.19 & -1.4 & 0.1 & 0.03 \\
\hline 13 & Riau & 0.6 & -1.7 & 0.3 & -0.8 & 0.02 & -1.6 & -0.8 & -0.2 \\
\hline 14 & South Sulawesi & -1.1 & 1.9 & -0.3 & 0.3 & -0.10 & 1.6 & -0.004 & 0.5 \\
\hline 15 & North Sumatera & -0.6 & -0.3 & 0.6 & -1.2 & -0.32 & -0.8 & -0.5 & -0.3 \\
\hline 16 & Jambi & 0.5 & -1.4 & 0.5 & -0.2 & -0.40 & -1.4 & -0.3 & -0.6 \\
\hline 17 & South Kalimantan & 0.1 & 1.7 & 1.3 & 0.3 & -0.71 & 2.3 & 1.6 & -0.6 \\
\hline 18 & West Sumatera & 0.0 & 1.3 & -0.2 & 1.4 & -0.73 & 2.8 & 0.4 & -0.4 \\
\hline 19 & West Nusa Tenggara & -2.4 & 0.3 & -0.5 & $-2,3$ & -0.8 & 1.3 & 1.6 & -1.0 \\
\hline 20 & Central Sulawesi & -1.9 & 0.7 & -1.6 & -0.8 & -0.8 & 1.4 & -0.9 & -0.1 \\
\hline 21 & Central Kalimantan & -1.2 & -0.9 & -0.3 & -1.4 & -1.5 & -0.2 & 0.1 & -1.5 \\
\hline 22 & South Sumatera & -1.0 & -0.8 & 0.3 & -1.2 & -1.6 & 2.6 & -0.004 & -1.3 \\
\hline 23 & North Maluku & 0.2 & -0.6 & -0.2 & -0.1 & -1.6 & -1.9 & -1.0 & -1.9 \\
\hline 24 & Lampung & 0.01 & -1.6 & 0.1 & -0.4 & -1.7 & -1.5 & 0.003 & -2.2 \\
\hline 25 & West Kalimantan & -1.4 & -0.9 & -0.5 & -1.9 & -1.8 & -1.1 & -0.1 & -2.1 \\
\hline 26 & Aceh & 0.2 & -0.4 & 0.5 & -0.4 & -1.8 & -0.9 & -1.2 & -1.5 \\
\hline 27 & Gorontalo & -2.2 & 3.7 & -0.7 & -0.3 & -2.0 & 4.0 & -1.2 & -0.4 \\
\hline 28 & Maluku & -3.4 & 3.5 & -2.9 & -1.1 & -2.1 & 2.8 & -1.9 & -0.8 \\
\hline 29 & West Papua & -2.3 & -1.7 & -3.2 & -1.3 & -2.1 & -0.6 & -2.1 & -1.5 \\
\hline 30 & Bengkulu & -0.8 & -0.6 & -0.5 & -0.9 & -2.4 & 0.1 & 0.3 & -2.7 \\
\hline 31 & Papua & -0.7 & 0.3 & -1.6 & 0.7 & -3.6 & 0.5 & -3.7 & -2.4 \\
\hline \multirow[t]{2}{*}{32} & East Nusa Tenggara & -5.0 & 0.1 & -2.6 & -3.7 & -4.6 & -0.5 & -1.3 & -4.4 \\
\hline & Indonesia & 0.007 & -0.002 & 0.02 & -0.06 & 0.64 & -0.29 & 0.04 & 0.73 \\
\hline
\end{tabular}

FNSI: Food and Nutrition Security Index; AV: Food Availability Index; AC: Food Accessibility Index; UT: Food Utilization Index 


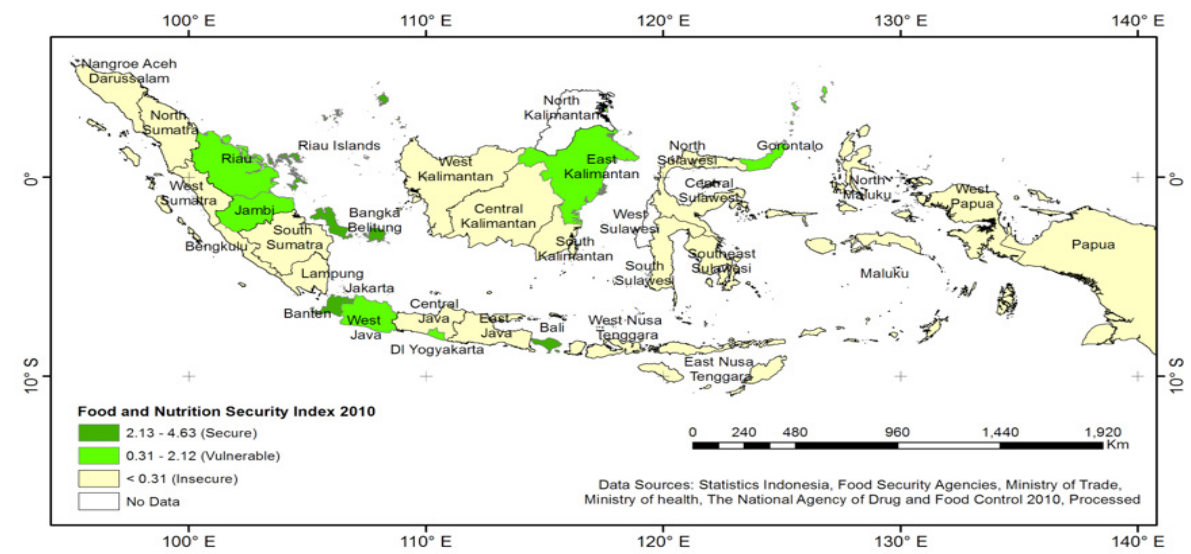

Figure 2. Distribution of regions in Indonesia based on food and nutrition security index in 2010

$(\mathrm{PC} 1=0.354)$, high prevalence of non-stunted under-five children $(\mathrm{PC} 1=0.353)$, and the high proportion of households with access to clean water $(\mathrm{PC} 1=0.346)$. This study showed that the provincial FNS achievement assosiated with nutritional status, food utilization dimension, and food accessibility dimension. Nutritional status of children under five was the outcome indicator of food security development and the key indicator of poverty and hunger alleviation as the global development targets in the achievements of MDGs and SDGs (WHO 2015; Suryana et al. 2016; FAO 2016).

The general characteristic of regions that were catagorized as food and nutrition secure indicated by the high proportion of households with adequate sanitation access. Jakarta and Special Region of Yogyakarta had the highest proportion ( $>80 \%)$ among other 32 provinces in 2010, while Bali Province had the highest proportion of water and sanitation access in 2013.
East Nusa Tenggara Province ranked at the last position in FNS achievement in 2010 and 2013. It assosiated with the high food vulnerability at the village level in this province; i.e. 44.9 percent of villages belonged to severe food-vulnerable and food-vulnerable categories (FSA 2015a). This situation was also influenced by the low household access to electricity, clean water, sanitation facilities, and high levels of poverty (Tono et al. 2016). Moreover, based on basic health research (MoH 2010 \& 2013), East Nusa Tenggara Provinces had the lowest proportion of non stunted under-five children (less than 50\%). Pangaribowo et al. (2013) stated that a healthy environment indicated by better access to sanitation and hygiene and health service infrastructure is also important. All of these aspects affect on the nutritional status of under five children.

There are several government policy and program to improve nutritional status such as the

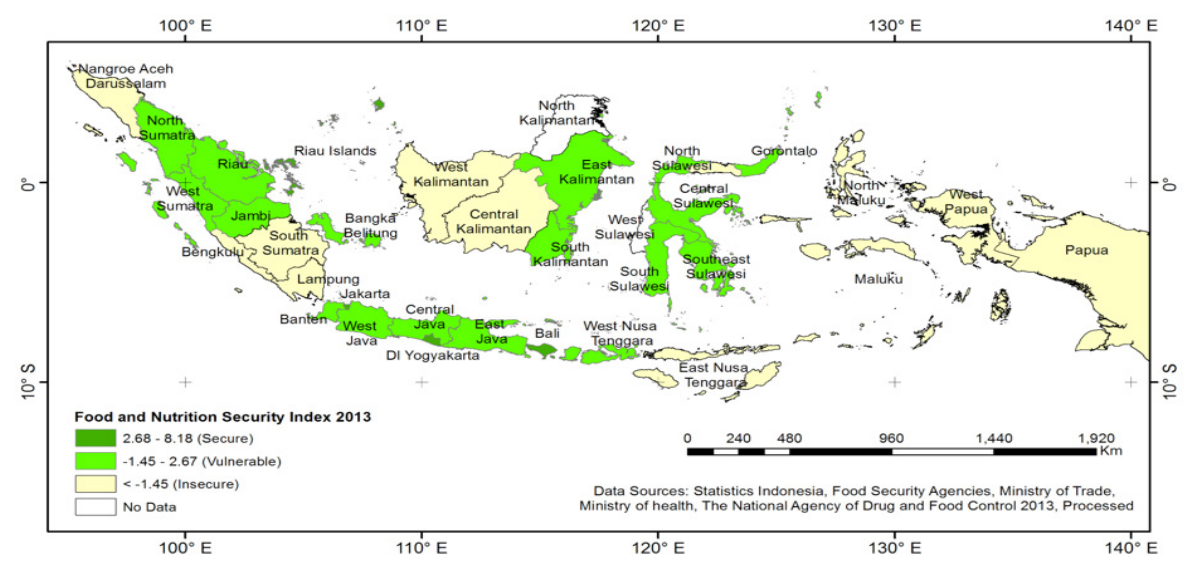

Figure 3. Distribution of regions in Indonesia based on food and nutrition security index in 2013 
program of nutrition in the first 1000 days where the government also set priority areas for stunting prevention in 100 districts/cities. In addition, there are other nutrition sensitive program such as the National Action Plan For Food and Nutrition, the government's conditional cash transfer, Program Keluarga Harapan (PKH) (Indonesian Conditional Cash Transfer Programme), WASH programs and other programs from related sectors (MoNDP 2010; TNP2K 2019; World Bank Group 2018).

In the past, Indonesia became a role model country for reducing high levels of malnutrition. However, nowadays therearetimes ofstagnant, setback, loss of attention (World Bank Group 2018). Increase in income equality and purchasing power is one of a key strategy to improve food access.

Applanaidu et al. (2014) explained that macroeconomic stability, economic growth and distribution are key factors in achieving food and nutrition security.Analysis from Purwantini(2014) also emphasized the importance of synergistic unification in food security development in Indonesia in line with the handling of nutritional problems. Victora et al. (2008) suggested that children aged two years that had suffered from stunting is the predictor for low-quality of human resources, which in turn would have negatively affected the nation's potential. Thus, the efforts to accelerate nutrition improvement require not only a nutrition spesific program but also a nutritionsensitive programs involving agricultural, social and education sectors, as well as food security (Ruel \& Alderman 2013). Therefore, multisector collaboration and nutrition-sensitive programs are essential in the synergy of health, nutrition, food security and food safety developments to achieve sustainable development goals (Black et al. 2016).

\section{CONCLUSION}

PCA on 23 selected indicators of food and nutrition security showed that the food and nutrition security achievement was still far from the expectation, indicated from the low index score especially in the eastern part of Indonesia. The lowest food and nutrition security achievement was found in East Nusa Tenggara Province in 2010 and 2013, while the best achievement was found in Riau Islands (2010) and Bali (2013). Although the two provinces had the best achievements, the nutritional problems in children under five were still found. The food availability dimension is generaly good nationally, however the food accessibility and utilization are still become the barriers for the food and nutrition security development. Hence, the action plan and strategy in midterm and longterm development to improve FNS performance should focus on improving access and utilization. Nutrition-sensitive program is the largest key component to improve the food accessibility performance and to sustain the food availability dimension, while nutrition-spesific program is a basic curative program to attain better food utilization performance.

\section{ACKNOWLEDGEMENT}

The authors would like to thank The Agricultural Extension and Human Resources Development Agency (BPPSDMP), Ministry of Agriculture as the scholarship sponsor. We would like to express our gratitude to National Institute of Health Research and Development, Statistics Indonesia, Food Security Agency, National Agency of Drug and Food Control of Republic of Indonesia, and Ministry of Trade for providing the research data. We would also like to give special thanks to Andi Alamsyah who has helped in the preparation of food and nutrition security maps.

\section{AUTHOR DISCLOSURES}

The author have no conflict of interest.

\section{REFERENCES}

Aliaga MA, Chaves-Dos-Santos SM. 2014. Food and nutrition security public initiatives from human and socioeconomic development perspective: Mapping experiences within the 1996 world food summit signatories. Soc Sci Med 104:74-79. doi:10.1016/j. socscimed.2013.12.025.

Applanaidu SD, Bakar NA, Baharudin AH. 2014. An Econometric analysis of food security and related macroeconomic variables in Malaysia: A vector autoregressive approach (VAR). UMK Procedia 1:93102. doi:10.1016/j.umkpro.2014.07.012.

Ariawan I. 2006. Indeks sosie-ekonomi menggunakan principal component 
analysis. Kesmas 1(2):83-87. http:// dx.doi.org/10.21109/kesmas.v1i2.317.

Black MM, Walker SP, Fernald LCH, Andersen CT, Digirolama AM, Lu C, McCoy DC, Fink G, Shawar YR, Shiffman J et al. 2016. Advancing early childhood development: From science to scale 1. Early childhood development coming of age: Science through the life course. The Lancet 389(10064):77-90. doi:10.1016/ S0140-6736(16)31389-7.

Capone R, Bilali HE, Debs P, Cardone G, Driouech N. 2014. Food system sustainability and food security: Connecting the dots. Journal of Food Security 2(1):13-22. http://doi. org/10.12691/jfs-2-1-2.

[CFS] Committee on World Food Security. 2012. Coming to terms with terminology food security, nutrition security, food security and nutrition, food and nutrition security. http://www.fao.org/docrep/meeting/026/ MD776E.pdf. [Accessed 20th October 2016].

[EIU] The Economist Intelligence Unit. 2016. Global Food Security Index 2016 an Annual Measure of The State of Global Food Security. London(UK): Dupont(GB).

[EIU] The Economist Intelligence Unit. 2017. Global Food Security Index 2017, Measuring Food Security and the Impact of Resource Risk. London (UK): Dupont (GB).

Faharuddin. 2012. Mengukur pencapaian penanggulangan kemiskinan dan kelaparan di Indonesia 2010. Jurnal Agro Ekonomi 30(2):145-157.

Fanzo J. 2014. Strengthening the engagement of food and health systems to improve nutrition security: Synthesis and overview of approaches to address malnutrition. Glob. Food Sec 3(3-4):183-192. doi:10.1016/j.gfs.2014.09.001.

[FAO] Food and Agriculture Organization. 2016. Food security indicators, FAOSTAT. http://www.fao.org/economic/ess/ ess-fs/ess-fadata/en/\#.WAupKuB97IU. [Accessed 23rd October 2016].

Finkayana IPA, Dewi MHU. 2016. Analisis pertumbuhan ekonomi dan indikator komposit ipm terhadap jumlah penduduk miskin di provinsi Bali tahun 2004-2013. EP Unud 5(7):861-881.
[FSA] Food Security Agency. 2015a. A Review of National Food Insecurity, collaboration between Food Security Agency and Statistics Indonesia. Jakarta (ID): Ministry of Agriculture Republic of Indonesia.

[FSA] Food Security Agency. 2015b. Food Consumption Directory 2015. Jakarta (ID): Ministry of Agriculture Republic of Indonesia.

[FSC \& WFP] Food Security Council and World Food Programme. 2009. Food Security and Vulnerability Atlas 2009. Jakarta (ID): FSC and WFP.

[FSC \& WFP] Food Security Council and World Food Programme. 2015. Food Security and Vulnerability Atlas 2015. Jakarta (ID): FSC and WFP.

Headey D. Ecker O. 2013. Rethinking the measurement of food security: From first principles to best practice. Food Security 5(3):327-343.doi:10.1007/s12571-0130253-0.

HerforthA,BallardTJ.2016. Nutritionindicatorsin agriculture projects: Current measurement, priorities and gaps. Glob Food Sec 10:1-10. doi:10.1016/j.gfs.2016.07.004.

Hjelm L, Mathiassen A, Wadhwa A. 2016. Measuring poverty for food security analysis: Consumption- versus asset-based approaches. Food Nutr Bull 37(3):275289. doi: $10.1177 / 0379572116653509$.

[IFPRI] International Food Policy Research Institute. 2014. Global Hunger Index: The Challenge of Hidden Hunger. Washington (US): IFPRI.

Jollife IT, Cadima J. 2016. Principal component analysis:A review and recent developments. Phil Trans R Soc 374(2065):1-16. https:// doi.org/10.1098/rsta.2015.0202

Karamizadeh S, Abdullah SM, Manaf AA, Zamani M, Hooman A. 2013. An overview of principal component analysis. Journal of Signal and Information Processing 4(3B): 173-175. doi:10.4236/jsip.2013.43B031.

Leroy JL, Ruel M, Frongillo E A, Harris J, Ballard TJ. 2015. Measuring the food access dimension of food security a critical review and mapping of indicators. Food Nutr Bull 36(2):167-195. https://doi. org/10.1177/0379572115587274.

[MoA] Ministry of Agriculture of Republic of Indonesia. 2010. Strategic Planning 
of Minisitry of Agriculture 2010-2014. Jakarta (ID): MoA RI.

[MoH] Ministry of Health of Republic of Indonesia. 2010. Basic Health Research in 2010. Jakarta (ID): MoH RI.

[MoH] Ministry of Health of Republic of Indonesia. 2013. Basic Health Research in 2013. Jakarta (ID): MoH RI.

[MoNDP] Ministry of National Development Planning, Republic of Indonesia. 2010. National Medium-Term Development Plan 2010-2014. Book I. National Development Agenda. Jakarta (ID): MoNDP.

[NA-DFC] National Agency of Drug and Food Control of Republic Indonesia. 2010. Strategic plan of NA-DFC 2010-2014. http://.pom.go.id/ppid/2010/rpusat/ksln. pdf. [Accessed 8th July 2017].

Napoli M, Muro P, Mazziotta M. 2011. Towards a food insecurity multidimensional index (FIMI). [Thesis]. Rome: University Degli Study.

Nurhemi, Soekro SRI, Suryani G. 2014. Pemetaan ketahanan pangan di Indonesia: Pendekatan TFP dan indeks ketahanan pangan. Working paper Bank Indonesia WP/4/2014:1-69.

Pangaribowo EH, Gerber N, Torero M. 2013. Food and nutrition security indicators: A review. Foodsecure. Project Working Paper 04, February 2013. http://www.foodsecure.eu/ PublicationDetail.aspx?id=13. [Accessed 2nd December 2016]

Pemberton C, Mgonja M, De Sormeaux A, Patterson-Andrews H, Mwaisango E. 2016. Food security: A comparison of indicators forthe United Statesand the United Republic of Tanzania. Journal of Food Security 4(4):95-103. doi:10.12691/jfs-4-4-3.

Purwantini TB. 2014. Pendekatan rawan pangan dan gizi: Besaran, karakteristik, dan penyebabnya. Forum Penelitian Agro Ekonomi 32(1):1-17. http://dx.doi. org/10.21082/fae.v32n1.2014.1-17.

Ruel MT, Alderman H. 2013. Nutrition-sensitive interventions and programmes: How can they help to accelerate progress in improving maternal and child nutrition? The Lancet 382(9891):536-551. doi:http://dx.doi.org/10.1016/S01406736(13):60843-0.

Suryana A. 2014. Menuju ketahanan pangan Indonesia berkelanjutan 2025: Tantangan dan penanganannya. Forum Penelitian Agro
Ekonomi 32(2):123-135. http://dx.doi. org/10.21082/fae.v32n2.2014.123-135. Suryana A, Arifin B, Hardinsyah, Achadi EL, Atmawikarta A, Martianto D, Hermanto, Sastraatmadja E, Lukman AS, Darmawiredja MR et al. 2016. Kebijakan Strategis Rencana Aksi Pangan dan Gizi Tahun 2016-2019. Jakarta (ID): Sekretariat Dewan Ketahanan Pangan.

Statistics Indonesia. 2014. Statistik Transportasi Darat 2014. https://www. bps.go.id/publication/2015/11/10/ dc32fd4a803f4fc29e $24 \mathrm{df} 4 \mathrm{~b} /$ statistiktransportasi-darat-2014.html. [Accessed 12th Desember 2016].

Statistics Indonesia. 2016. Statistik Indoensia 2016. Jakarta (ID): Badan Pusat Statistik.

[TNP2K] Tim Nasional Penanggulanagn Kemiskinan. 2019. Working paper 472019: Priority Regions for Prevention of Stunting. http:/www.tnp2k.go.id/ download/8831947WPstuntingENGF.pdf. [Accessed 21st September 2020].

Tono T, Juanda B, Barus B, Martianto D. 2016. Kerentanan pangan tingkat desa di provinsi Nusa Tenggara Timur. J Gizi Pangan 11(3):227-236. https://doi.org/10.25182/ jgp.2016.11.3.\%25p.

Victora CG, Adair L, Fall C, Hallal PC, Martorell R, Richter L, Scahdev HS. 2008. Maternal and child undernutrition: Consequences for adult health and human capital. The Lancet 371(9690): 340-357. doi:10.1016/ S0140-6736(07)61692-4.

[WHO] World Health Organization. 2012. Nutrition Landscape Information System (NLIS). Country Profiles Indicators. Interpretation Guide. Geneva $(\mathrm{CH})$ : WHO

[WHO] World Health Organization. 2015. Nutrition Targets and Indicators for the Post-2015 Sustainable Development Goals. Accountability for the Measurement of Results in Nutrition. A Technical Note. http://www.unscn.org/files/Publications/ Post 2015_Nutrition_Targets and Indicators final March 2015 website ${ }^{-}$ pdf. [Accessed 2nd December 2016].

World Bank Group. 2018. Aiming High: Indonesia's Ambition to Reduce Stunting. http://documents1.worldbank.org/curated/ en/913341532704260864/pdf/128954REVISED-WB-Nutrition-Book-AimingHigh-11-Sep-2018.pdf. [Accessed 22nd September 2020]. 